\title{
The Serving Men of New Zealand Studio Furniture, 1979 to 2008
}

\author{
D WOOD
}

\begin{abstract}
New Zealand's first comprehensive research on its furniture making history (1830-1900) was published in 2006. This paper adds to that history by summarizing the record of studio furniture, defined as one-of-a-kind and individually made. The narrative begins with studio furniture's inaugural collective incorporation in 1978, its growth and peak through the 1980s and its disappearance from public view towards the dawn of the new millennium. The state of studio furniture design and making today concludes the discussion.
\end{abstract}

In their inspection of the exhibits under this head, the Jury took into their consideration the following points - viz., general workmanship; design; illustration of the ornamental woods of the Colony; and decoration where resorted to. Speaking of the furniture exhibits generally, the Jury feel themselves justified in expressing praise of the taste, variety, and workmanship displayed. The numerous ornamental woods with which New Zealand abounds, afford great scope for the exercise of the higher efforts in cabinet-work, and for the display of decorative art in furniture. ${ }^{1}$

A century and a half ago, the Jurors of furniture for the 1865 International Exhibition in Dunedin expressed their optimism for the future of the industry in New Zealand. For a population of approximately 185,000 Europeans, there were more than 200 furniture making enterprises in the new colony at the time. ${ }^{2}$

At the end of the next century another exposition, Framed: a Studio Furniture Survey 1997, considered the medium. Assessed by curators instead of a jury, this exhibition was summarized in similar terms: "For a sparsely populated country, and working in the (perhaps) seemingly narrow field of furniture within that small country, there is extraordinary depth and diversity of activity among furniture designers in New Zealand." 3 While Framed was a snapshot of its time just as the Industrial Exhibition had been, the future for furniture was more problematic than in 1865 .

These figurative bookends highlight a craft practice that has existed in New Zealand for generations, in a range of genres from expedient cottage craft to small shop work to industrial production. Its venerable processes and historical practitioners have received recent scholarly attention. ${ }^{4}$ Yet there is a variety of New Zealand furniture that has not been acknowledged or recorded. This variety, which was formalized in the late 1970s and in the public arena for about twenty years, is called studio furniture; because many of its practitioners are now in their 50s and $60 \mathrm{~s}$, it is timely that the absence of this history be redressed. ${ }^{5}$

What is studio furniture? How was it manifest in New Zealand? Who were its practitioners? Where were studios located? And why was its climactic exhibition problematic? This paper considers the "serving men" of studio furniture in Aotearoa/New Zealand. ${ }^{6}$

\section{Definition of Studio Furniture in New Zealand}

The term "studio furniture" emerged in the United States in 1989. ${ }^{7}$ It was further developed in 1999. The uniqueness of this variety of furniture is due to the education and experience of the furniture makers; their abilities to combine design, materials, and technique; and small shop production. For the most part, American makers have learned and mastered design and construction at a tertiary education facility, rather than serving an apprenticeship, though some are self-taught. In addition, learning is updated by means of periodicals, books, short-term 
courses, and experimentation, as well as comparing notes with peers. These makers have "a high degree of visual literacy." 8 The work is sold in galleries and at exhibitions; pieces are usually commissioned unless the maker sells samples from an exhibition or showroom.

Does this definition readily transpose to New Zealand? Notably, I discovered that the expression "studio furniture" is not universally recognised and used by practitioners or the general public. Curators have called it "contemporary furniture practice," "craft art" and "one off" furniture, or "alternative." The public understands "bespoke" meaning "engaged beforehand." Given that there are no entrenched titles and "studio furniture" is acceptable to most practitioners, I use that designation. ${ }^{10}$

What does it entail nationally? By means of surveying about thirty practitioners I determined that the majority of the traits evident in the United States apply in New Zealand: highly skilled makers; one-of-a-kind production; small shops; consumption of woodworking books and magazines, workshop attendance, networking with other makers; and sales via galleries, exhibitions, and commissions. The discrepancy with American counterparts lies in the rarity of participation in tertiary studies. A few makers learned their skills via formal or informal apprenticeships but most are self-taught, inspired initially by a workshop or using workshops to enhance knowledge and technique.

The result is that conceptual furniture - driven by a message or story rather than function - appears rarely. New Zealand studio furniture makers are participants in and knowledgeable of art precedents and popular culture, yet it could not be said that there is evidence of "a high degree of visual literacy." Educational exposure to a range of art sources and materials has not occurred, so that incorporation of such references is not within the comfort zone of most New Zealand makers. Experimentation with new materials, which often happens in an educational context, is not financially viable for the isolated solo practitioner. ${ }^{11}$

As a consequence, makers are more likely to become expert in the characteristics of and appropriate techniques for a limited palette of materials, primarily readily available wood species and orthodox metals. In summary, with the exception of education, Cooke's definition of studio furniture applies in New Zealand. With this definition in hand, I will examine studio furniture's presence in the latter part of the twentieth century.

\section{Studio Furniture pre-1979}

The British Arts and Crafts Movement, which championed the small shop designer-craftsman, was antecedent to New Zealand studio furniture. The most recognized professional exponents of the style were James Walter Chapman-Taylor (1878-1958), his son Rex, and grandson Jack. ${ }^{12}$ James Chapman-Taylor, an architect, met Arts and Crafts practitioners, C.F.A. Voysey, M.H. Baillie Scott and Ernest Gimson, during trips to England. ${ }^{13}$ He designed and/or built 97 homes in this country and also created furniture. Rex worked with his father for almost 20 years beginning in 1924. He built a workshop north of Wellington in 1940 where he made craftsmanstyle tables, chairs, chests of drawers, cabinets and fireplace surrounds that found their way into homes locally as well as in Europe, the United Kingdom, Australia and North America. ${ }^{14}$ Jack became his father's apprentice in 1946. 


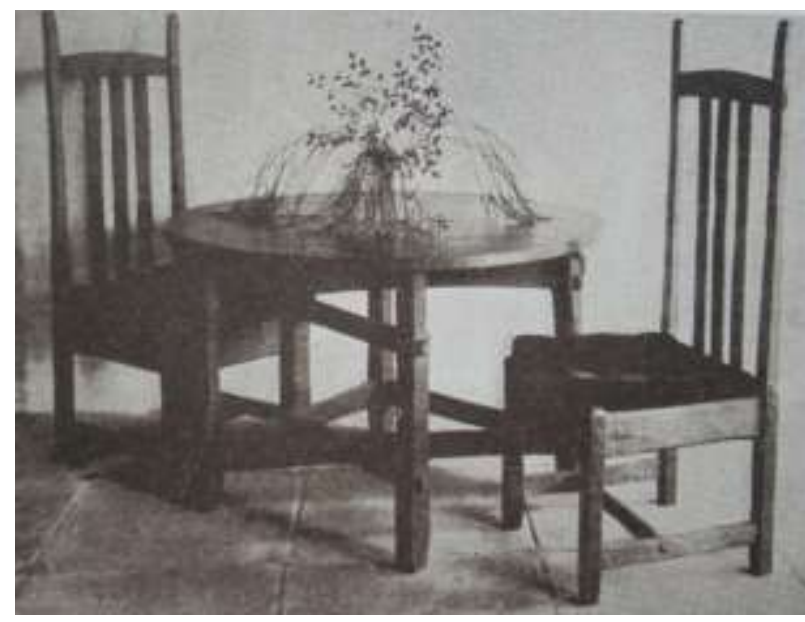

Figure 1: James Walter Chapman-Taylor Furniture. Table and chairs of Jarrah, c. 1913 Courtesy of Judy Siers, Millwood Heritage Productions, P.O. Box 12246, Ahuriri, Napier, New Zealand, 2007. The Life and Times of James Walter Chapman-Taylor: 391, Plate 767.

Neither Rex nor Jack Chapman-Taylor was formally associated with contemporary craft, but their work was known. Carin Wilson, one of the "whos" of New Zealand studio furniture, provided this recollection:

... a friend of mine who I was at school with showed me a piece of furniture. He lived in Wellington ... and there was a custom in the family whereby ... when each of the children reached a certain age, it may have been sixteen or eighteen or something, they were given a piece of furniture for their bedroom and the piece of furniture was always a piece manufactured by the Chapman Taylor workshops in the Hutt Valley. That, as far as I can recall, was the first piece of furniture that I saw which spoke to me in a way that said, this is something different and there is design and there's workmanship and there's thought that's gone into this piece that steps far beyond what is normally invested in the production of a piece of furniture. ${ }^{15}$

While the Chapman-Taylors are readily identified as early- to mid-twentieth century makers, Peter Smeele is not. A contemporary of Rex Chapman-Taylor during the 1960s, Smeele was a furniture maker and craft entrepreneur who immigrated from Holland in 1952. ${ }^{16}$ He opened the Brown's Mill Market in Auckland in 1968, a craft cooperative that included potters and weavers. Yet Smeele's name does not appear in the Crafts Council of New Zealand's Register of Craftspeople. ${ }^{17}$ Neither is it listed in the Index of New Zealand Artists, Craftsmen and Designers created by the Auckland Museum. ${ }^{18}$ New Zealand certainly had architect/designers who created furniture in this period - Garth Chester and Ernst Plischke to name only two - but they were not responsible for manufacture of their designs.

The first indication of the presence of furniture makers who identified themselves with craft occurred in the June 1971 membership list of the World Crafts Council. ${ }^{19}$ My rationale for seeking evidence of studio furniture via the Crafts Council of New Zealand (CCNZ) is that no national network of individual makers existed until $1986 .{ }^{20}$ The New Zealand Furniture Manufacturers' Federation, which is now the Furniture Association of New Zealand Inc., while recognizing "solo crafts people producing one-off designs" as furniture manufacturers, did not embrace soloists. ${ }^{21}$ Concurrently, the New Zealand Industrial Design Council (1967-1988) directed its energies to industry. ${ }^{22}$ Although some furniture makers probably chose not to join the CCNZ, its rolls provide the only record of solo practitioners. 


\section{Official Studio Furniture}

There is a hiatus of nine years before furniture or woodworking activities are noted again in CCNZ newsletters. In November 1980 came the announcement of the existence of the Canterbury Guild of Woodworkers (in Christchurch) with Carin Wilson as founding President. ${ }^{23}$ Wilson described the organization as "the first social co-operative of furniture makers who worked together to achieve better results in the practical aspects of their craft." 24 Wilson began his woodworking career in the early 1970s by making furniture for his family from found materials like kauri tubs and an old gate. He exhibited from the beginning: an entire 1974 exhibit was purchased by McKenzie and Willis, the Christchurch furniture retailer. From 1975 to 1979 he shared a studio with James Pocock, producing one-of-a-kind furniture for McKenzie and Willis under the label Adzmarc.

The Christchurch area had enough woodworkers in 1979 to begin the Guild with fourteen members. For instance, Colin Slade, who completed a chairmaking apprenticeship in High Wycombe, England, immigrated to New Zealand in 1972 and found employment as a herd tester for the Auckland Livestock Improvement Association. ${ }^{25}$ On a tour of the South Island in 1976 he decided to join a craft cooperative in Christchurch and resumed his chairmaking. ${ }^{26}$ Also in 1976, David Thurston, whose first major commission was cases for grandfather clocks, set up his shop 50 miles southeast in Akaroa. ${ }^{27}$ David Putland and Iain Wilkinson were also in the vicinity. ${ }^{28}$ The Guild staged its initial formal exhibition at the Canterbury Society of Arts (CSA) Gallery in October 1980 enabling a membership of woodturners, furniture makers, carvers and a toymaker to display their work for two weeks; $70 \%$ was sold. ${ }^{29}$

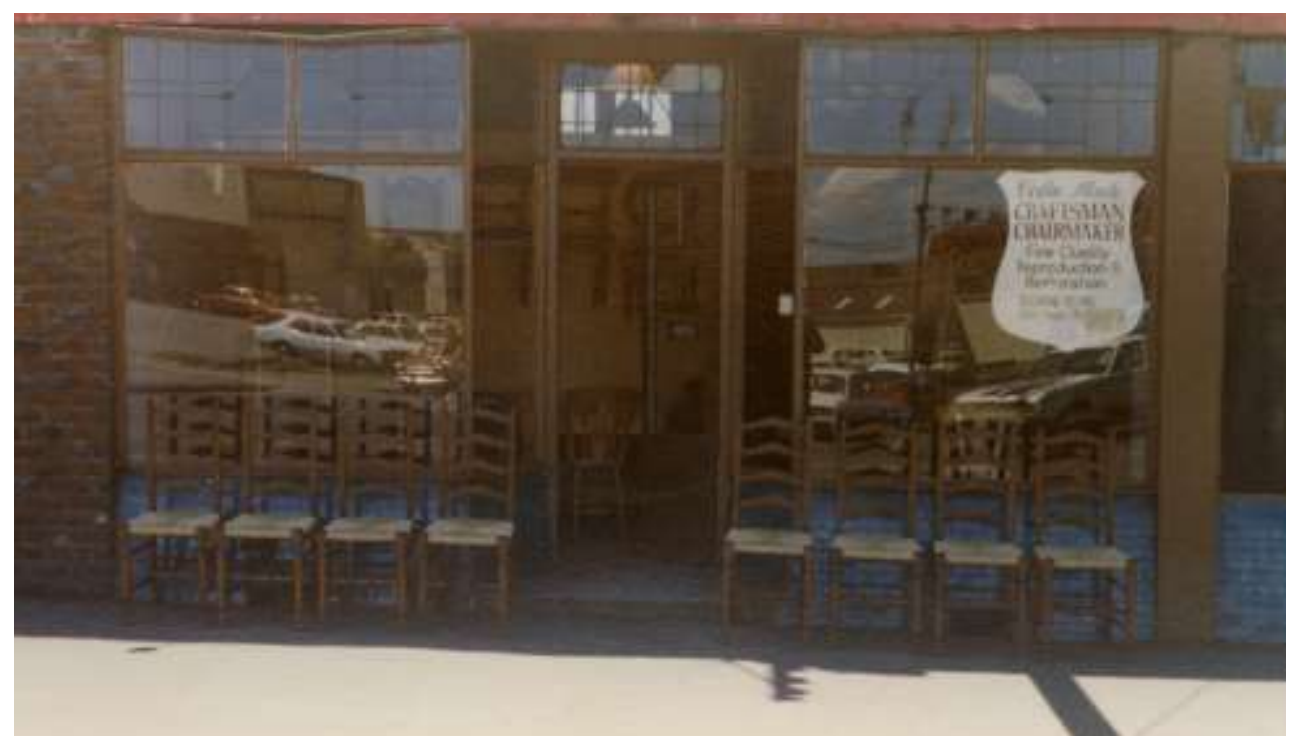

Figure 2: Colin Slade's Showroom \& Workshop, Ferry Road, Christchurch, 1978-1982 Taken in December 1980, the sign on the window states, "Colin Slade Craftsman Chairmaker Fine Quality Reproduction \& Restoration." Photo courtesy of Colin Slade.

In other parts of the country, a Taranaki Guild formed in $1982 .{ }^{30}$ The Auckland Guild progressed from idea to reality following the first Fine Woodworking Exhibition at Compendium Gallery in 1983. ${ }^{31}$ The Guild was incorporated on March 15, 1983 and held its first exhibition to coincide with James Krenov's visit in July, discussed below. Also in 1983 John Shaw instigated the Nelson Guild. Born in Newcastle-upon-Tyne, Shaw went to primary, intermediate and secondary school in Hamilton (New Zealand), and left in July 1980 in search 
of furniture-making training. He enrolled at Rycotewood College in England in 1981, and passed Ordinary and Advanced City and Guilds of London Institute requirements for furniture. Shaw returned to New Zealand in 1982 where he set up a studio in Nelson. He placed an advertisement proposing a guild and attracted 30-40 makers with varying levels of interest and skill. $^{32}$ Wellington woodworkers got together in 1984. ${ }^{33}$ Meetings in Marlborough and Northland started in $1985 .{ }^{34}$ The Guilds facilitated local networking and enthusiastic exchanges of woodworking lore. Simultaneously, activity at the national level provided increasing educational and community opportunities.

Wilson's presidency of the Canterbury Guild led to his accession as the Southern Regional Representative on the Executive of the CCNZ. Wilson was the first furniture craftsman to sit on the Executive, and this had repercussions for the recognition of studio furniture. Firstly, a voice was raised to draw attention to furniture makers' interests in an organization that had been dominated by potters and weavers. ${ }^{35}$ Woodworking events and resources began to appear in newsletters. Secondly, when Wilson was elected President in August 1981, the CCNZ was anticipating its second national conference. Kevin Perkins, a noted Tasmanian furniture maker, was a guest at the conference in January 1982; while in New Zealand he gave a lecture in New Plymouth and a workshop in Christchurch. ${ }^{36}$ A woodworking representative had to be at the table to nominate Perkins as a presenter.

Third, Wilson's personal agenda, education, arose out of the experience of being unable to find appropriate training in furniture making rather than carpentry. As a consequence, the theme of the 1982 Conference was Craft Education. And it was resolved that a five-year plan for education be conceived, including encouragement of future generations of craftspeople by means of tuition subsidies.

To fulfill this mandate, Wilson approached the Queen Elizabeth II Arts Council for a grant to "enable me to visit some of the most influential art schools in the world and talk to senior people ... and get curriculum ideas from them, photograph what was going on there, have a look at the studio facilities...." 37 His report to the Minister of the Arts in 1984, and passed on to the Director-General of Education, included all craft media, but Wilson's passion for and expertise in woodworking meant that American and European facilities for furniture making were closely looked at and emulated in his recommendations.

The immediate impact of Wilson's overseas trip was invitations to James Krenov and Alan Peters; they came to New Zealand in 1983 and 1984 respectively. Krenov founded the cabinetmaking program at the College of the Redwoods in Fort Bragg, California in $1981 .^{38}$ Wilson viewed that College. Krenov wrote four books which were known to New Zealand makers. ${ }^{39}$ One of those makers, Humphrey Ikin, described their influence:

When I was young I was very inspired by those James Krenov books. They can seem a bit quaint now ... but they were just so influential at the time. It was someone speaking from the heart about that passion of living with their work and that's what I related to, getting really close to his work whether you liked his finished objects or not.... He was so loose but he was also so refined.... So that timing was really important for me - no two ways about that, and that was a bit of a universal thing, wasn't it? Right round the western world there were people who were influenced by those ... but it wasn't the way the work looked that influenced me so much as that beautiful connection of material with a way of life, and all those things that he expressed so well. ${ }^{40}$

Ikin, for whom an interest in furniture was galvanized during his early twenties on a trip to Europe, was self-taught. He returned to his homeland in the late 1970s and set up a woodworking shop where he experimented with design ideas that embodied a South Pacific identity. 
When Krenov visited with the assistance of a Fulbright Scholarship, his workshops in Auckland, Wellington and Christchurch were sold out. ${ }^{41}$ His lectures in Rotorua, the Hawkes Bay and Nelson were presented to standing-room-only audiences. Six months later, Alan Peters, sponsored by the British Council, was a speaker at the CCNZ Conference held at Lincoln College, Canterbury. ${ }^{42}$ Peters' contribution to New Zealand practitioners was stated by a participant in one of his subsequent workshops: "Nelson craftsmen, mostly the professional people, seemed delighted to hear from Alan Peters, that it is possible to combine a business approach and uncompromising craftsmanship." 43

Carin Wilson's motive in bringing these men to New Zealand was "to grow the sense of community and designers." 44 In addition, New Zealanders were given models towards which they should strive. James Dowle's recollection was typical:

His [Krenov's] visit had a profound and lasting effect on many of us that were fortunate enough to attend-we all learned so much in a short time and I still enjoy using the matai plane that I made under his guidance. I also recall returning to my workshop after his visit to finish off a half-built sideboard. I was so ashamed of the great clunky dovetails that were reliant on epoxy glue to hold together and fill the gaps, but fortunately the customer still thought it was marvelous.

I must concede that I earned virtually nothing through this period and was very dependent on the income of my new wife. She even allowed me to attend the Alan Peters workshop in the first week of our honeymoon, here in Nelson with John [Shaw], David [Haig], Jimu [Grimmett] and others from all over the country. Alan Peters' training under Edward Barnsley brought an entirely different perspective to Jim Krenov-still devoted to integrity in design and construction, but much more concerned about communication with the client and systems to run a good business. I needed this message. ${ }^{45}$

Enthusiasm for Krenov and Peters prompted invitations to other visitors: Jon Brooks (American), Art Carpenter (American) and Richard La Trobe-Bateman (British). Familiarity with these teachers also encouraged New Zealanders to drop by workshops in the United States and England. Jimu Grimmett, a former furniture maker in Nelson, recalled:

I've been travelling quite a few times to the States and hoped to meet Sam Maloof at one of these woodworkers' seminars or an event. And I got talking to him and he said, "Ahh, from New Zealand. When you're passing through Los Angeles, call in." So I called in and ended up working for him. For six weeks. I left there and made my way to Japan, following up interests in Japan. And he wrote to me, saying come back if you'd like to. So I went back and spent three months with him that time....

I also worked for, not worked for him, but I spent time with Art Carpenter in Bolinas, just outside San Francisco. Went and saw him and ended up staying there a week and helping. That's what I did in those days. ${ }^{46}$

Prior to the early 1980s New Zealand furniture makers read the literature by and about overseas "stars." With woodworking having a national profile and the Crafts Council (plus individuals) becoming adept at soliciting grants, New Zealand was no longer isolated from what was happening in the worldwide community. At the same time, Wilson's travel report was percolating through government ministries to affect national craft education. 


\section{Furniture Education}

Members of the CCNZ worked with the Department of Education to introduce a Certificate in Craft Design at nine polytechnics throughout the country starting in February 1986. The curricula were dedicated to instruction in a variety of craft media as well as two- and threedimensional design; wood was part of the prospectus at all nine. By 1988, when the Diploma in Craft Design came on stream, the Nelson Marlborough Institute of Technology (NMIT) was the primary deliverer of furniture instruction. Its full-time tutor was John Shaw, whose skill set and reputation had advanced as a consequence of the overseas visitors. ${ }^{47}$

Like Humphrey Ikin, Shaw was influenced by Krevov's writing: "I was introduced to Jim Krenov's books which was the first time I had come into contact with his philosophy. To anyone in my situation the way he talks about wood was a revelation." 48 Admiration of the books prompted Shaw to attend Krenov's Wellington workshop. The American invited Shaw to come to the College of the Redwoods and, with the assistance of the Queen Elizabeth II Arts Council, Shaw spent nine months in California during 1984-85.

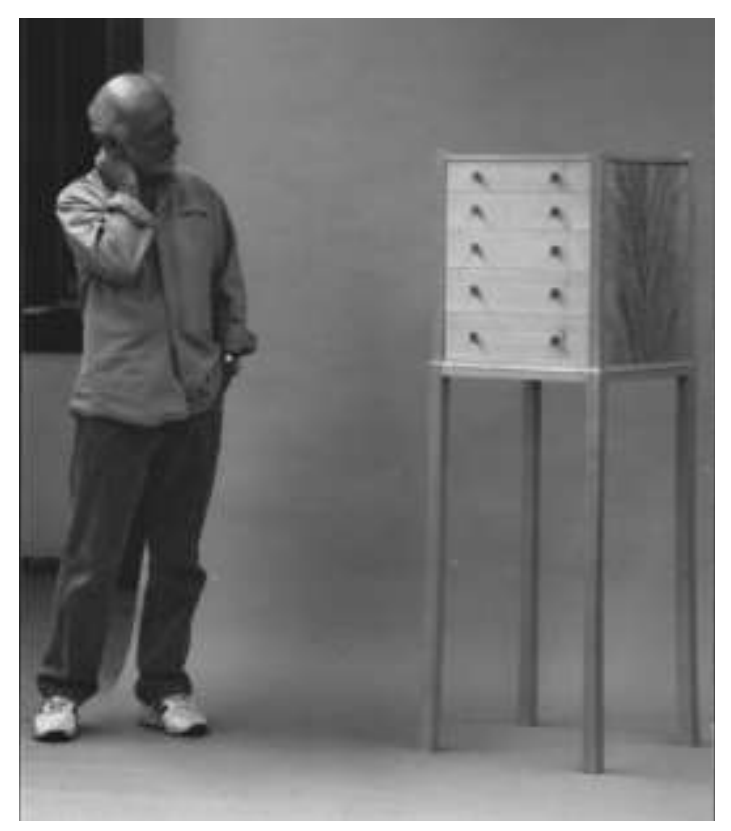

Figure 3: James Krenov \& John Shaw's Cabinet, Pacific maple \& yew

The cabinet, a design based on a gentleman's shaving cabinet, was made for an exhibition while Shaw was at the College of the Redwoods. The photo is labelled in Shaw's hand: "My teacher and mentor James Krenov." Photo courtesy of John Shaw.

Shaw returned to Nelson in September 1985 and was immediately hired by NMIT, for two years, to draft a curriculum in fine woodworking for their new craft and design certificate. ${ }^{49}$ Thirteen years later Shaw left NMIT, by which time the Institute's emphasis had shifted from craft techniques to creativity, and from furniture to wood sculpture. His departure, which he believes was partly due to the natural cycle of life, was also predicated on institutional changes due to a nation-wide reorganization of the structure of education.

Until 1989 the polytechnics were under the purview of a Department of Education that attempted to provide similar opportunities to residents throughout the country. With the Education Act 1989, polytechnics were given free rein in their delivery of curricula thereby initiating competition with each other. For a variety of reasons-increased revenue from a 
broader arts offering, lack of craft teachers, the expense of operating craft programs - many shifted to a visual arts focus. Institutions that had woodworking studios and instruction in furniture-making abandoned these courses. ${ }^{50}$ The facilities were absorbed into sculpture departments. While students could still specialize in furniture under the visual arts umbrella, comprehensive training towards becoming a craft master was not available.

Rather than furniture design and making, New Zealand polytechnics now offered instruction in industrial or product design. Some students had the benefit of being taught by makers such as Humphrey Ikin (at Unitec) and Tim Miller (at Victoria University). ${ }^{51}$ These few received advice on technique and assembly (to achieve quality prototypes), but the ultimate aim of the training was design for industry.

Two exceptions to the industrial design model emerged. In 1997 the Universal College of Learning (UCOL) in Palmerston North began offering a Diploma in Furniture Design and Making. ${ }^{52}$ The program is the only public one, and at $\$ 6,643$ per year for a two year, full-time course, it is affordable. UCOL's website states that it offers "a practical, hands-on experience with lecturers that are qualified furniture makers. The practical component makes up $80 \%$ of the programme." ${ }^{, 53}$ In the South Island, although John Shaw resigned in 1999 to return to making, he admits that he "always fantasized about a fine furniture school in Nelson." 2004, a financial backer came forward permitting a serious search for premises. Collaborating with his brother-in-law, David Haig, Shaw inaugurated a beginners' cabinetmaking class one afternoon per week using personal equipment; at the same time, funding permitted promotion and the establishment of a charitable trust to operate the school as a business. The Centre for Fine Woodworking (CFW) held its first class in dedicated premises in September 2006; the first graduates of the nine-month, full-time course displayed their finished products on 11 December 2007. ${ }^{55}$

\section{Collectivity and Voice}

Accomplishments by 1983 warrant iteration: guilds in Christchurch, Taranaki, Auckland and Nelson; woodworking exhibitions in Christchurch and Auckland; a woodworking presence in the CCNZ and its events; overseas visitors; and a resolution to champion craft education. The palpable energy inspired a recognized Christchurch woodturner, Noeline Brokenshire, to inaugurate a national woodworking magazine in November $1983 .{ }^{56}$ As editor and publisher of Touch Wood, Brokenshire explained her initiative:

Over the last few years New Zealand has experienced a revolution in the handcrafts. Pottery, fibre art, weaving, glass work, jewellery, have shown a vast increase in interest and participation. The number of craftsmen has swelled and the quality of artistry is bringing world recognition.

Wood craft, established longer than many of its fellow crafts, has been slow to slough off its traditional fetters but our numbers have risen and creative design has become more explorative, and quality of execution has acquired new, high standards.

But - we have no national body, not much communication between one woodworker and another and no national means for transfer of ideas. In short, no printed magazine peculiar to this country.

Touch Wood could become that medium for communication and, together with the rise of regional woodworking guilds, it may set a pattern for a new dialogue. ${ }^{57}$

Touch Wood was well written and competently edited; it carried a range of articles that included Guild news, maker profiles, exhibition reviews, technical know-how, design, timber resources and advertising. Brokenshire solicited articles from subscribers as well as 
researching and writing many herself; her editorials consistently advocated for design, professionalism and a national organization for woodworkers. ${ }^{58}$

After fourteen issues, in March 1988, Brokenshire gave up ownership. She passed the baton to the new owner/editor, Malcolm Macpherson, who renamed the publication The New Zealand Woodworker. The format changed from A4 to A3 with the Spring 1990 edition; the subsequent issue (\#24) contained complaints about the tabloid size and was the last, in the summer of 1991. Nothing replaced it. With the loss of The New Zealand Woodworker in 1991 and Craft New Zealand in 1993, studio furniture was the victim of a publicity vacuum.

Leading makers could not have foreseen this eventuality, yet had already taken steps to establish and sustain an independent presence. In July 1986 more than 25 furniture makers gathered for two days in Wellington to address the critical need for a national organization. Classifying themselves as designer/makers, the group specified its objective as providing "a leading edge to continuing development of a high quality and innovative furniture identity." 59 Instigated by Colin Slade, John Shaw and Humphrey Ikin, the Association of Designers \& Furniture Makers New Zealand required submission of slides and a curriculum vita for membership. ${ }^{60}$ It was later known as The Furniture Group: Independent Designer/ Furniture Makers of New Zealand Inc. ${ }^{61}$ Its aims were primarily to promote public awareness of professional furniture designer/makers. The Group wanted to share expertise through apprenticeships and seminars using New Zealand and international practitioners, and to be a collective voice for furniture marketing strategies and promotion of furniture design/making as a vocation. It would raise standards of quality and excellence through exhibitions and foster communication with others in related fields, thereby ameliorating the effects of working in isolation. Worldwide contacts would be pursued, and intercultural exchange promoted. Significantly, the makers wanted to influence resource management regarding specialized timber usage, including lobbying for appropriate plantings of timber trees, and coordination of distribution of quality domestic trees appropriate for furniture making. ${ }^{62}$

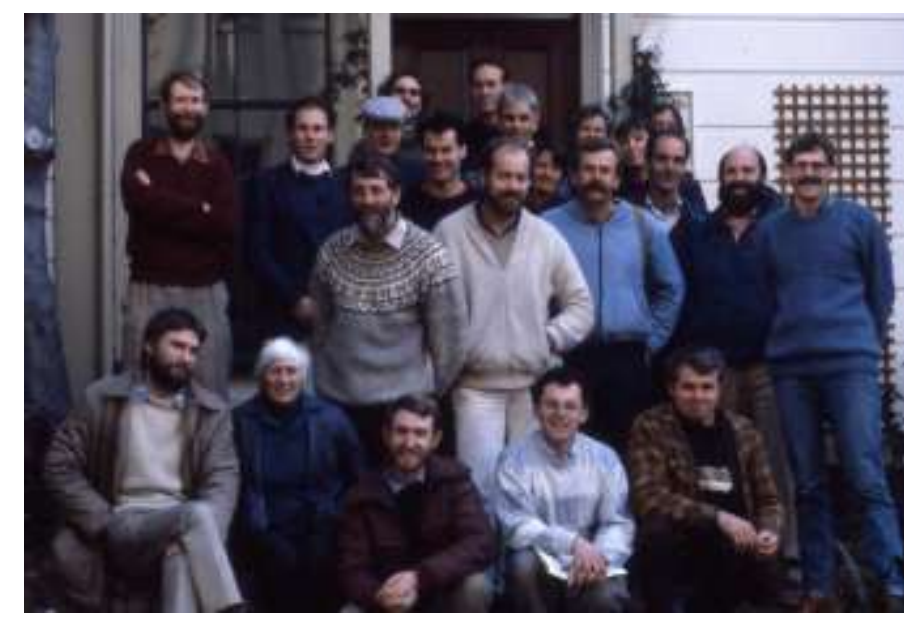

Figure 4: The Furniture Group Inaugural Meeting, 19/20 July 1986

Back: Roland Siebertz, Humphrey Ikin, Carin Wilson, Harriet Lukens, Ilana Becroft? (just forehead and eyes)

Row 3: Colin Slade, Chris McElhinney, Marcel Creyghton, François Aries, Karen Hight (?), David Haig, Marc Zuckerman

Row 2: Vic Matthews, Mark Christensen, Howard Tuffery, James Dowle

Front: John Shaw, Noeline Brokenshire, Chris Thompson, Remi Couriard, Jimu Grimmett. Photo curtesy of Colin Slade. 
These objectives were sound, thoughtful and future-oriented. But membership stood at little more than two dozen, there was physical (and psychological) distance between isolated pockets of production (Auckland, Hawkes Bay, Wellington, Nelson and Christchurch were the nodes for studio furniture), and limited income precluded the expense of flying to national gatherings. The Furniture Group had an Annual Meeting in 1988 in Auckland to coincide with the New Zealand Contemporary Furniture Exhibition where thirteen members attended. ${ }^{63}$ The aims/manifesto above came out of a Seminar and Annual General Meeting held in July 1989, again coinciding with an exhibition, Quality by Design, in Wellington. ${ }^{64}$ The Group was mentioned again in the October 1991 edition of Craftnews, with leadership shifting to Hawkes Bay. ${ }^{65}$ It then "fizzled out." 66

A national studio furniture collective was gone, but what happened to the Guilds? Collegial beginnings gave way to acrimony as some makers matured, specialized and began to earn a living at their craft: professionalization meant that careerists had different concerns and interests than hobbyists. Later issues of The New Zealand Woodworker showed strength in some clubs while others foundered. For instance, at a meeting on 4 July 1990, with only six members in attendance, it was determined that the Auckland Guild of Woodworkers had "no future" and its affairs would be "wound up." ${ }^{67}$ Some groups remained viable because of diversified foci (turning, carving, houseware/ toymaking). Perusal of the internet today finds woodworking guilds and associations throughout the country including the National Association of Woodworkers Inc. But the NAW is devoted to woodturning; there is no association of one-of-a-kind furniture makers. The deaths of the Furniture Group, the Crafts Council of New Zealand in July 1992 and Craft New Zealand in the final months of 1993 inhibited evidence of studio furniture and all craft media.

\section{Studio Furniture on Display}

When studio furniture was au courant in New Zealand in the 1980s and 1990s, prominent venues, both public and private, held solo or group furniture shows. The Guilds had regular public and private displays of members' work. In addition, other exhibitions, beginning in 1983, brought recognition to studio furniture, thereby identifying professional wood artisans and advancing their careers. Four significant ones are detailed below. By 2007, when Objectspace in Auckland mounted ShowRoom, the curators stated that they were motivated to undertake a furniture exhibition because the previous one had been ten years ago. ${ }^{68}$ The curators were referring to the last of the four exhibitions, Framed.

\section{a) The Alternative Furniture Show}

Christchurch is New Zealand's second largest furniture manufacturing centre. ${ }^{69}$ Thus, it is not surprising that the city hosted the first major studio furniture exhibition as a counterpart to the annual Canterbury Furniture Manufacturers Federation exhibition. In September 1982 Colin Slade and Iain Wilkinson assembled nine practitioners willing and able to commit $\$ 500$ each to mount Solid Wood: the Alternative, as a means to inform the public of the alternatives to manufactured products. The Canterbury Horticultural Hall, close to the manufacturers' Christchurch Town Hall venue, was hired. The wife of the Mayor of Christchurch, Lady Hay, opened the show, attracting radio, television and press coverage. Solid Wood's juxtaposition with the longstanding Furniture Fair brought publicity in itself. Slade noted: "an enormous number of people found themselves for the first time in the presence of craft and were unable to resist touching, sitting on and exclaiming about the things they were seeing ... their obvious delight was shared by the makers." 70 


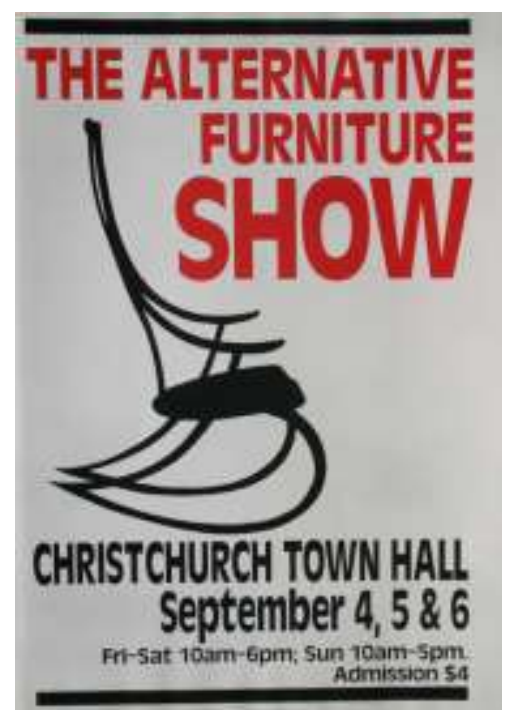

Figure 5: Poster for The Alternative Furniture Show, 1992 Silhouette of David Haig's Rocker. Courtesy of James Dowle.

The Alternative Furniture Show (the phrase "solid wood" was dropped) occurred annually from 1983 to 1993. In a review of the 1985 edition, Noeline Brokenshire proposed that the Crafts Council or the Queen Elizabeth II Arts Council consider funding a touring exhibition of selected pieces so that "all New Zealanders would be exposed to alternative designs and particularly to well-crafted furniture." 71 Neither agency took up the challenge, but in 1986 the Alternative organizers displayed twenty pieces in Nelson, and in July 1989 mounted a facsimile called Quality by Design: The Best of New Zealand Designed Furniture in Wellington. ${ }^{72}$ Dunedin saw an edition of the Show in March 1992. ${ }^{73}$

The high point for the series was 1988, with twenty-two exhibitors "showing an excitingly wide variety of work." "In 1992 there were only twelve participants, of whom two were new. The last Alternative Furniture Show was staged in October 1993. In its eleven years of existence it maintained a reputation as a showcase for "fine individual craftsmanship."75 The other end of the spectrum, innovative furniture design, was served by Artiture.

\section{b) Artiture A6 $^{76}$}

The First Annual Artiture Exhibition took place in a "dilapidated old Queen Street building" in Auckland in $1987 .{ }^{77}$ The outré setting suited the aim of the organizers, which was "to design furniture that was art, not constricted by the necessity of the pieces having to be a commercial proposition." Their inspiration was post-modernism and the Memphis Group's espousal that furniture could be art, and design overruled traditional materials, forms and functions. ${ }^{78}$ Unlike the Alternative Furniture Shows (AFS), the first Artiture had few makers: the participants were primarily designers whose work was made by others. ${ }^{79}$

The second rendition, opening in June 1988 at an upscale commercial gallery, included a few more makers. Sales did not match those for the South Island AFS, which may have been due to the furniture's incompatibility with New Zealand domestic environments - for instance, Greg Smith's sculptural aluminium chair or Diana Firth's garden ensemble (Figure 6). Furniture requires a considerable financial investment and a buyer assesses a new piece's compatibility with what is already owned. Smith's chair would not suit the majority of New Zealand homes, and Firth's colourful and charming Bird Folly fitted the Webster's Dictionary definition: "foolish and useless but expensive undertaking." 


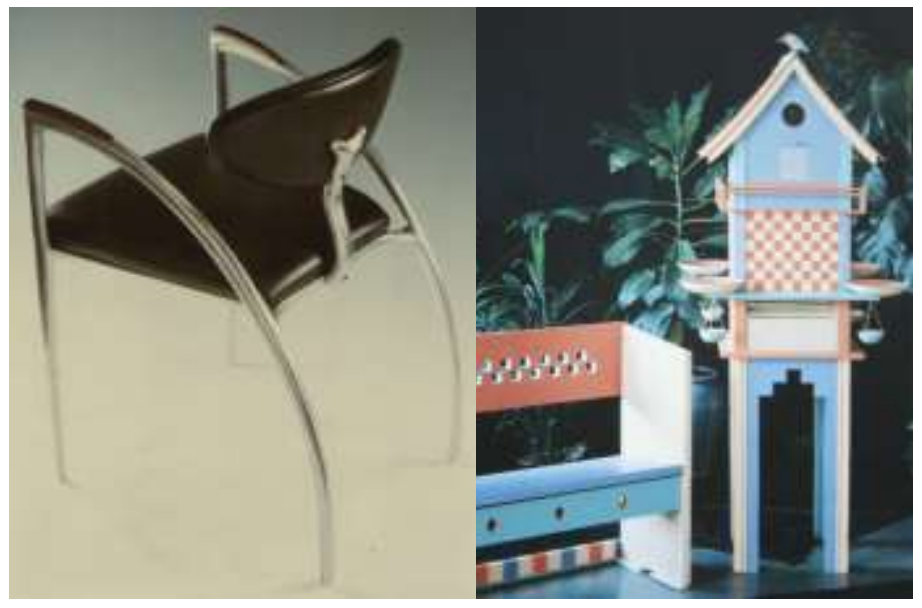

Figure 6: Greg Smith. Nevada. Aluminium, leather. Diana Firth. Bird Folly. 1987 Courtesy of Greg Smith.

http://www.museumworkshop.co.nz/images/smithg\%20futura\%20chair.jpg

Firth, a clothing designer, painted the bird box and bench with acrylic, complementing its 'folly' nature. Courtesy of Diana Firth. Douglas Lloyd-Jenkins. At Home: a Century of New Zealand Design. Auckland: Godwit, 2004. Page 264, Plate 1.

The fifth Artiture (1991) was staged at the Auckland Museum, conferring on it a high profile and many viewers. It also had a commercial sponsor, Levene Paints, permitting publication of a catalogue of the thirty juried pieces. ${ }^{80}$ The following year, selections from 1991 toured six venues in five cities in Japan. ${ }^{81}$ The Japanese display also included work by Humphrey Ikin, Kazu Nakagawa and David Trubridge. ${ }^{82}$ In 1994, when the original conveners, including Carin Wilson, called it quits, no individual or team came forward to produce a substitute. ${ }^{83}$

Artiture and the Alternative Furniture Show were antithetical. The AFS was almost solely wood whereas Artiture showed varied materials-metal, glass, clay tiles, fiberglass, plastic. The $A F S$ was set up as a trade show; Artiture modelled art exhibitions. The AFS catered to designer/makers; Artiture demonstrated how designers, with the assistance of industry, could produce slick prototypes for urban design. The opposing shows were a healthy happenstance for studio furniture. But in their final incarnations the "edge" was gone from each. Slade put it this way: “... if both these shows are disappearing in opposite directions, one must wonder what the future holds for the presentation and consequent survival of the mainstream furniture movement." 84

Not only divergent styling, however, threatened the survival of the furniture movement: a nation-wide economic recession from 1987 to 1992 affected all discretionary spending. ${ }^{85}$ One of the eternal perils for studio furniture is that its purchase is forgone in periods of financial stress.

\section{c) The Contemporary Furniture Exhibition}

In June 1988 the New Zealand Contemporary Furniture Exhibition was announced. The Auckland Museum, in conjunction with New Zealand Home \& Building, invited designers and furniture makers, regardless of discipline or media, to participate in "the premier showcase in 1988 for new furniture designed and made in New Zealand." 86 Selections would be based on their "originality of design and skill of execution" and displayed at the Museum from 2 to 18 September. 


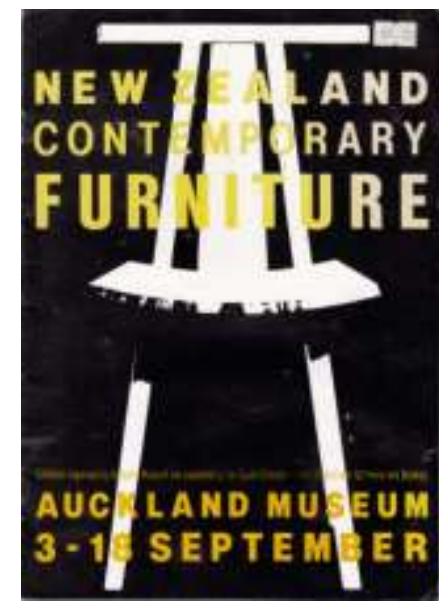

Figure 7. Catalogue Cover, New Zealand Contemporary Furniture Exhibition Humphrey Ikin's matai Dining Chair (1985) is the central graphic. Courtesy of Auckland War Memorial Museum Tāmaki Paenga Hira and Humphrey Ikin.

As mentioned previously, the Furniture Group identified exhibitions as one of its mandates, and joined with the Museum to conceptualize and facilitate the exhibition. The initial response was enthusiastic with over ninety expressions of interest. ${ }^{87}$ Seventy-five entries were shipped to Auckland but only twenty-four met the criteria of the judge, George Ingham, Head of the Wood Workshop at the Canberra School of Art. Ingham's exclusion of works by prominent designers and makers sent shock waves through the community and prompted a hastily assembled Salon de Refusés. The Salon, initially endorsed by Ingham and the Museum to permit the public to judge for itself, became suspect because it was not limited to the rejected work. Neither was the work in the same state as when it was judged. ${ }^{88}$ Nevertheless the resulting publicity was better than money could buy.

From the selected entries, David Trubridge's Occasional Chair was purchased by the Museum. ${ }^{89}$ It employed kauri and rosewood whereas the materials in the exhibition ranged from pressed pineboard to corrugated iron, steel and glass. Colin Slade summed up the importance of both Contemporary Furniture and the Salon de Refusés:

...on the one hand is the art world which refuses to admit the craft of furniture as a discipline worthy of respect, and on the other hand is the industry with too few examples of fine art furniture to be inspired by, and a strong consumer profit motive to deter it from being so inspired. It's a wonder that there is any furniture of individual merit being produced in this country, and the fact that there is is a credit to the perseverance and dedication of the small band of people in that movement. ${ }^{90}$

The Contemporary Furniture Show was a synopsis of studio furniture in 1988; Framed represented the state of affairs ten years later.

\section{d) Framed}

Framed: A Studio Furniture Survey 1997 was an initiative of the Dowse Art Museum in Lower Hutt where it was on display from 5 April until 2 July. This national show, inviting makers to create new work, was co-curated by Humphrey Ikin and Carin Wilson. Ikin's catalogue essay described how he and Wilson were overwhelmed by the number and diversity of entries. As a result, Framed was their interpretation of "studio furniture" at that time:

So the exhibition became, in effect, a slice through to highlight this cross-section: the work of younger designers who had not exhibited previously, alongside the not so 
young; experienced practitioners beside recent design graduates. There are those for whom making all their own work is an essential part of both the process and the result, and those who always prefer to utilize the production skills of others. There are pieces which are clearly "one-off," for reasons of both idea and means, with those for which there is the intent and real possibility of considerable ongoing production, and finally there are pieces which use "furniture" more as subject-matter than outcome, alongside the most pragmatic by choice. ${ }^{91}$

There were twenty-three exhibitors. Materials included aluminium sheet, medium density fiberboard, steel, rattan, glass bricks and various hard- and soft-woods; aesthetics varied amongst high tech, industrial, minimalist and contemporary. Framed was a snapshot, taken by Ikin and Wilson, of New Zealand studio furniture in 1997; unintentionally, it was the Alternative Furniture Show and Artiture side by side.

As an epilogue to Framed I discovered, in the archives of the Crafts Council of New Zealand, three "Open Letters" from exhibitors David Haig, David Trubridge and Tim Miller. They were writing in response to a letter from Carin Wilson that followed a Forum held in conjunction with Framed; the meeting was an attempt to find cohesion amongst makers.

Haig, the craftsman's craftsman, stated that he felt no affinity with the industrial design on display: "I personally feel I have much more in common with craft-artists in completely different media, than with many of those whose work is represented in 'Framed.' I'm certainly not saying that this work has no validity, simply that I cannot see the common interest or relevance with my own work." 92 Trubridge, whose portfolio has gravitated from handcrafted to electronically-manufactured during his career, has a foot in both camps. He asserted that the problem was diversity: "There isn't enough common ground. We are all coming from different directions with totally different agendas." 93

Miller, an industrial designer, wrote: "Things have changed in the last ten years.... In my view a new breed of furniture makers has emerged. They are trained as designers and as designers they explore a far wider range of materials expressing their inherent qualities and combinations to achieve the best unique effects. Many 'designed' pieces of furniture are still made in small workshops and in small batches." He summarized the polarity:

There are two types of furniture makers. One is a designer maker and the other is the artist crafts person. I believe that there is a difference between the two. In my view, this is where the problem lies and was the source for the conflict of opinion at the forum. ${ }^{94}$

The polarity, epitomized by Framed, encapsulates the state of New Zealand's studio furniture today.

\section{Conclusion}

In the United States, Cooke's research on studio furniture encompassed a large enough population of artist craftspeople that he did not have to lump them together with product designers. His seminal catalogue, New American Furniture: the Second Generation of Studio Furnituremakers, defined a field into which John Shaw, Colin Slade, Humphrey Ikin and Carin Wilson readily fit. My craft history which begins in 1979, the year the Canterbury Guild of Woodworkers was formed, is dedicated to 20 years during which the designer and the maker were the same person. Borrowing Cooke's nomenclature, the second generation of New Zealand furniture designer/makers are no longer studio furniture makers according to the adopted definition. Even though they now have the tertiary education that was missing in the past, it is not the tertiary education specific to craft. This new breed of designer/makers will, in the future, warrant their own page in history. 
I began with a quotation cited by William Cottrell. His research unearthed a previously hidden segment of New Zealand's design and social history, namely furniture's abundant existence and production in the nineteenth century. Similarly, my research shows that twentyfirst-century makers of studio furniture, hidden amongst ponga ferns and in back streets of urban centers, once had twentieth century predecessors who were recognized.

\footnotetext{
${ }^{1}$ William Cottrell, Furniture of the New Zealand Colonial Era: An Illustrated History 1830-1900 (Auckland: Reed, 2006), 479.

${ }^{2}$ Ibid, 263.

${ }^{3}$ Humphrey Ikin, “Curators' Essays," Framed: A Studio Furniture Survey 1997 (Lower Hutt: Dowse Art Museum, 1997), 3.

${ }^{4}$ In addition to Cottrell, there is S. Northcote-Bade, Colonial Furniture in New Zealand (Auckland: Reed, 1971); Patricia De Lautour, A New Zealand Guide to Antique and Modern Furniture (Wellington: Grantham House, 1993); Douglas Lloyd-Jenkins, At Home: A Century of New Zealand Design (Auckland: Godwit, 2004); and Brian Peet, The Seuffert Legacy: New Zealand Colonial Master Craftsmen: The Craft of Anton Seuffert \& His Sons William, Albert \& Carl (Auckland: Icarus
} Publishing, 2008). Cottrell's book is the most extensive and reliable furniture resource. It won the 2007 Montana Book Award for Reference and Anthology, and the New Zealand Society of Authors E.H. McCormick Best First Book Award for Non-Fiction. Book Publishers Association of New Zealand. http://bpanz.org.nz/?p=1. Accessed 5 December 2009

${ }^{5}$ Although there are errors in De Lautour's account, she is to be commended for concluding her book with a selection of small New Zealand manufacturers and one-of-a-kind makers, from both North and South Islands, whose names would otherwise be lost. Lloyd-Jenkins includes significant designers from the 1950s and 60s but confines his history to three studio furniture makers.

${ }^{6}$ Rudyard Kipling provides my title and questioning:

I keep six honest serving-men

(They taught me all I knew);

Their names are What and Why and When

And How and Where and Who. ("The Elephant's Child," Just So Stories, 1902.)

Preference for the male gender is also relevant and warrants specific mention. There are very few female furniture makers in New Zealand and this absence can be speculated on: lack of women teachers and, therefore, role models; an agricultural economy in which women's leisure was devoted to homemaking (baking, quilting, preserving, dressmaking); a conservative society in which women adopted traditional modes of expression; crafts like pottery being seen as more suitable; women's magazine articles, from 1960 to 2000, rarely featuring female furniture makers (designers yes; makers no). This gender discrepancy, compared to North America, warrants investigation in the future. Within this paper, the focus is men who have served the studio furniture medium. It is an adaptation of one of the thesis chapters of my PhD, begun in 2009, dedicated to New Zealand studio furniture.

${ }^{7}$ Edward S. Cooke, Jr., New American Furniture: The Second Generation of Studio Furnituremakers (Boston: MFA Publications, 1989), 2.

${ }^{8}$ Edward S. Cooke, Jr., "Defining the Field," in Furniture Studio: the Heart of the Functional Arts, ed. John Kelsey and Rick Mastelli (Free Union, VA: Furniture Society, 1999), 10.

${ }^{9}$ For "contemporary furniture practice," see Objectspace, ShowRoom (Auckland: Objectspace, September - October 2007). For "craft art" and "one off furniture, see Suter Te Aratoi a Whakatu, Weyerhaeuser Studio Furniture Awards, 2000 (Nelson, N.Z.: The Suter Te Aratoi a Whakatu, 2000); Suter Te Aratoi a Whakatu, Weyerhaeuser Studio Furniture Awards 2002 (Nelson, N.Z.: The Suter Te Aratoi a Whakatu, 2002). For “alternative," see Te Papa, Simply Pacific: New New Zealand Design (Wellington: Te Papa, Museum of New Zealand, 2000).

${ }^{10}$ The term was used in well-known exhibits, Framed: A Studio Furniture Survey 1997 and the Weyerhaeuser Studio Furniture Awards, 2000 and 2002. 
${ }^{11}$ While I attended the Rhode Island School of Design, DuPont donated quantities of Corian and a pizza oven to the Furniture Department so that students could experiment with bending the heated material.

${ }^{12}$ I am grateful to Mark Stocker for bringing to my attention his research on Frederick George Gurnsey (1868-1953) who made and carved ecclesiastical and domestic furniture in Christchurch.

${ }^{13}$ Judy Siers, The Life and Times of James Walter Chapman-Taylor (Napier: Millwood, 2007), 91.

${ }^{14}$ Alex Gillett, "Made to Last," Listener \& TV Times (February 26, 1990): 102-103, p. 103.

${ }^{15}$ Carin Wilson, personal interview, 26 March 2009, transcript 1-9, 3. Wilson was born in 1945 so he would have seen this furniture in the early 1960s.

${ }^{16}$ Douglas Lloyd-Jenkins, At Home: A Century of New Zealand Design (Auckland: Godwit, 2004), 200-203.

${ }^{17}$ A project undertaken by the CCNZ national office in mid 1982.

${ }^{18}$ The Index was begun in 1989 by Justine Olsen. It was judiciously kept in its early days but suffered through several regime and personnel changes. It is now updated by a volunteer. An Exhibition of New Zealand Craft Work lists Smeele amongst an eminent list of craftspeople including potters and weavers. He showed two coffee tables, a milking stool and a model of a desk and was described as an "interior and shop designer" and "designer of individual furniture." Auckland City Art Gallery. An Exhibition of New Zealand Craft Work, August 1959.

http://www.aucklandartgallery.govt.nz/research/digitalresources/cat33.asp.

Accessed 7 December 2009.

19 "List of Members," WCC Newsletter, June 1971, 1-8. New Zealand joined the World Crafts Council in 1965; in 1977 the organization revised its constitution and changed its name to the Crafts Council of New Zealand Inc. (representing the World Crafts Council). CCNZ Newsletter, November 1977: 1. A summary of a discussion concerning the appropriateness of furniture for a craft exhibition appeared in 1970. The consensus was that it must be handcrafted, "not produced in mass for commerciale [sic] sale." s World Crafts Council. Minutes of the Annual General Meeting of the WCC, 26 July 1970 (no pagination).

20 "Resource Centre," New Zealand Crafts 18 (Spring 1986): 37-38, p. 38.

${ }^{21}$ David Palmer, "Manufacturing Industries: Furniture Manufacturers Look to Polish Up Their Image," New Zealand Manufacturer (September 1998): 32-37, p. 32.

${ }^{22}$ Department of Statistics New Zealand, New Zealand Official Yearbook, 1971 (Wellington: Govt Printer), 1007.

23 "Guild of Woodworkers," Crafts Council News (November 1980): 6.

24 “Art and Industry," New Zealand Crafts 21 (Winter 1987): 14-16, p. 14.

${ }^{25}$ Colin Slade, Curriculum Vitae, undated c. 1984.

${ }^{26}$ Holly Blair, "Colin Slade: Chairmaker Craftsman,” New Zealand Crafts 13 (Summer, 1984): 10-12, p. 10.

${ }^{27}$ Mike Crean, "Wooden Heart," Christchurch Press (11 March 2002), 19.

${ }^{28}$ Putland and Wilkinson were part of New Zealand's first major exhibition, Solid Wood: The Alternative, Christchurch, 1983.

29 "Guild of Woodworkers," Crafts Council News (November 1980): 6.

${ }^{30}$ New Zealand Crafts [no number] (September 1982), no pagination.

${ }^{31}$ Humphrey Ikin, “Auckland Woodworkers Guild News," Touch Wood 1 (November 1983): 23.

${ }^{32}$ John Shaw, personal interview, 22 March 2008, interview notes.

33 "In Touch" (3), Touch Wood 3 (July 1984): 26-27, p. 26.

34 "In Touch" (6), Touch Wood 6 (July 1985): 22-25, p. 25.

35 "Taxation on Crafts," New Zealand Crafts 1 (July 1982): 15.

36 "Kevin Perkins," Crafts Council News (December 1981): 2.

${ }^{37}$ Carin Wilson, personal interview, 26 March 2009, transcript 1-9, p. 5.

${ }^{38}$ College of the Redwoods, "James Krenov: Summary," http://www.crfinefurniture.com/ 1pages/shopinfo/jkobit.html Accessed 7 December 2009.

${ }^{39}$ A Cabinetmaker's Notebook (1976), The Fine Art of Cabinetmaking (1977), The Impractical Cabinetmaker (1979), and Worker in Wood (1981), all published originally by Van Nostrand Reinhold.

${ }^{40}$ Humphrey Ikin, personal interview, 31 March 2009, transcript 1-18, p. 17-18. 
${ }^{41}$ Christine Ross, "From the Executive Director," New Zealand Crafts 6 (July 1983): 5.

42 "Conference '84: Alan Peters," New Zealand Crafts (December/January 1984): 8-9, p. 8.

43 "Alan Peters: The New Zealand Workshops - February/March 1984," Touch Wood 3 (July 1984): 5-8, p. 5.

${ }^{44}$ Carin Wilson, personal interview, 26 March 2009, transcript 1-9, p. 6.

${ }^{45}$ James Dowle, personal email, 21 November 2009.

${ }^{46}$ Jimu Grimmett, personal interview, 18 January 2008, transcript 1-10, p. 2. Sam Maloof (19162009), identified by Cooke as one of the "First Generation" American studio furniture makers (Cooke 1989, 13), did not come to New Zealand.

${ }^{47}$ Howard Tuffery was the part-time wood tutor at Wanganui Regional Community College; he spent a brief period working with Kevin Perkins in Australia. Chris Gibson, "A Commitment to Craft," Touch Wood 10 (November 1986): 9-10.

${ }^{48}$ John Shaw, "John Shaw: Furniture," New Zealand Crafts 23 (Autumn 1988): 29-30.

${ }^{49}$ John Shaw, personal interview, 22 March 2008, interview notes.

${ }^{50}$ The program at NMIT was terminated in 2001.

${ }^{51}$ Miller studied at Rycotewood College, as did John Shaw, and emigrated to New Zealand in 1994 to teach Industrial Design (Framed, inside back cover). He is currently on the faculty at Victoria University of Wellington.

${ }^{52}$ Andy Halewood, personal interview, 29 April 2008.

${ }^{53} 2016$ fees. https://www.ucol.ac.nz/programmes/trades/diploma-in-furniture-design-and-making Accessed 17 July 2016.

${ }^{54}$ John Shaw, personal interview, 22 March 2008, interview notes.

${ }^{55}$ Centre for Fine Woodworking. www.centre-for-fine-woodworking.co.nz Accessed 7 December 2009.

${ }^{56}$ Edward Cooke points out that this inclusiveness and collegiality extended by a woodturner is unknown in the United States where furniture makers and woodturners remain in distinctively separate camps. Brokenshire stated that New Zealand is too small to separate the disciplines of furniture making and turning. Noeline Brokenshire, personal interview, 18 March 2010, interview notes.

${ }^{57}$ Noeline Brokenshire, “This First Issue," Touch Wood 1 (November 1983): 2.

${ }^{58}$ Noeline Brokenshire, "Plane View," Touch Wood 6 (July 1985): 2; "Plane View: Changing Hands," Touch Wood 14 (March 1988): 2-3; "Plane View: Furniture Design," Touch Wood 2 (March 1984): 23; "Plane View: The Professional Image," Touch Wood 12 (July 1987): 2.

59 "Resource Centre," New Zealand Crafts 18 (Spring 1986): 37-38, p. 38.

60 “Association of Designers \& Furniture Makers New Zealand," New Zealand Crafts 15 (Summer 1985): 24.

61 "Clubs, Guilds, Groups and Associations," New Zealand Woodworker 17 (December 1988): 4-5, p. 4.

${ }^{62}$ James Dowle, "Furniture Group," New Zealand Crafts 28 (Winter 1989): 50.

63 "Clubs, Guilds, Groups and Associations," New Zealand Woodworker 17 (December 1988): 4-5, p. 4.

${ }^{64}$ Brian Grouden, "Two Months in the Life...," New Zealand Woodworker 20 (Summer 1989): 29.

65 "Allied Organisations Contacts," Craftnews 35 (October 1991): 8.

${ }^{66}$ James Dowle, personal email, 21 November 2009.

67 "Sad Death of a Craft Guild," New Zealand Woodworker 23 (Spring 1990): 1.

${ }^{68}$ I attended ShowTell, a one-day symposium on 6 October 2007, during which the curators talked about the exhibition, and some of the makers elaborated on their work.

${ }^{69}$ Jason Conway, "Yesterday's Trees and Tomorrow's Technology: The Competitiveness of the New

Zealand Wood Furniture Industry," (unpublished master's thesis, University of Auckland, 1999).

${ }^{70}$ Colin Slade, "Solid Wood: The Alternative," New Zealand Crafts 9 (March/April 1984): 22-25, p. 25 .

${ }^{71}$ Noeline Brokenshire, "The Alternative Furniture Show '85," Touch Wood 7 (November 1985): 2022, p. 22.

72 "Roundup," New Zealand Woodworker 19 (June 1989): 12.

${ }^{73}$ Charmian Smith, "Range of Furniture at Show," Otago Daily Times (21 March 1992): 22. 
${ }^{74}$ Colin Slade, "The Alternative Furniture Show," Craft New Zealand 41 (Spring 1992): 26.

${ }^{75}$ Ibid

${ }^{76}$ I am grateful to Edward Cooke for alerting me to Arthur Espenet Carpenter's article "The Rise of Artiture," Fine Woodworking 38 (January/February 1983): 98-103. Carin Wilson visited Carpenter in 1982 and thinks the expression was aired then Carin Wilson, personal email, 23 July 2010).

${ }^{77}$ Nanette Cameron, “Artiture," New Zealand Crafts 22 (Spring 1987): 14-16, p. 14.

${ }^{78}$ Jonathan Woodham, Twentieth-Century Design (Oxford: Oxford University Press, 1997).

${ }^{79}$ Peter Rogers, metalworker and dealer in Art Deco and 50s furniture; Marilyn Sainty and Diana

Firth, clothing designers; Jan Hewitt, architectural student; Mike Tree, furniture designer; Biz

Dempster, watercolour artist; Paul van Omnen, photographer; Michael Glock, interior designer.

Cameron op.cit.

${ }^{80}$ Vicki Holder, "Artiture Begs the Question," New Zealand Home \& Building (October/November 1991): 52-53, p. 52.

${ }^{81}$ Carin Wilson, "HB Furniture," New Zealand Home \& Building (August/ September 1992): 116118,120 , p. $118 \& 120$.

${ }^{82}$ Ikin, Nakagawa and Trubridge did not show at Artiture 1991; their work is present in installation photos in Japan (Wilson, "HB Furniture" 118,).

${ }^{83}$ Helen Schamroth, "After Artiture," Listener (10 December 1994): 42-43.

${ }^{84}$ Colin Slade, "The Alternative Furniture Show," Craft New Zealand 41 (Spring 1992): 26.

${ }^{85}$ Dr Alan Bollard (Governor of the Reserve Bank) addressed the Property Council of New Zealand in 2004: "The bubble burst in late 1987 when the US share market crashed. It suddenly became obvious that asset prices had been out of line with economic fundamentals. We had witnessed a sustained period of misplaced investment, with the returns from this investment proving to be low... The consequences for New Zealand were serious. Some companies went bankrupt and the economy went into a recession. It didn't recover from this recession until 1992. In terms of the loss of output relative to potential output, this recession was probably New Zealand's second worst of the twentieth century." (Alan Bollard, "What's happening in the property sector?" Speech to the Property Council of New Zealand, 2 September 2004 http://www.rbnz.govt.nz/speeches/0156216.html Accessed 8 December 2009.

${ }^{86}$ Auckland Institute \& Museum, "Announcement and Entry Form," New Zealand Woodworker 15 (June 1988): inside front cover. Later information added support from the Queen Elizabeth II Arts

Council. "Exhibitions," New Zealand Woodworker 16 (September 1988): 14-15.

${ }^{87}$ Lynne McCarthy, "Review: Art or Craft?" New Zealand Home \& Building (December 1988/January 1989): 115-117, p. 116.

${ }^{88}$ According to Olsen, some pieces had been improved. "The New Zealand Contemporary Furniture Show Down," New Zealand Crafts 26 (Summer 1988): 7-8, p. 8.

${ }^{89}$ Justine Olsen, “Auckland Museum's Trubridge chair,” New Zealand Woodworker 17 (December 1988): 34 .

${ }^{90}$ Colin Slade, "If It's Craft It's Art," New Zealand Crafts 26 (Summer 1988), 9-12, p. 12

${ }^{91}$ Humphrey Ikin, "Curators' Essays," Framed: A Studio Furniture Survey 1997 (Lower Hutt: Dowse Art Museum, 1997), 3.

${ }^{92}$ David Haig, unpublished open letter (May 1997).

${ }^{93}$ David Trubridge, unpublished open letter (May 1997).

${ }^{94}$ Tim Miller, unpublished open letter (May 1997). 